\title{
MKRN3 and KISS1R mutations in precocious and early puberty
}

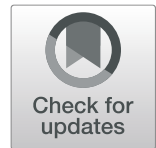

\author{
Sara Pagani ${ }^{1}$, Valeria Calcaterra ${ }^{1}$, Gloria Acquafredda ${ }^{2}$, Chiara Montalbano $^{1}$, Elena Bozzola ${ }^{3}$, Pietro Ferrara ${ }^{4}$, \\ Manuela Gasparri ${ }^{5}$, Alberto Villani ${ }^{3}$ and Mauro Bozzola ${ }^{1 *}$ (D)
}

\begin{abstract}
Background: Pubertal timing is known to be influenced by interactions among various genetic, nutritional, environmental and socio-economic factors, although the ultimate mechanisms underlying the increase in pulsatile $\mathrm{GnRH}$ secretion at puberty have yet to be fully elucidated. The aim of our research was to verify the role of KISSR1 (previously named GPR54) and MKRN3 genes on pubertal timing.
\end{abstract}

Methods: We analyzed the DNA sequence of these genes in 13 girls affected by central precocious puberty (CPP) who showed onset of puberty before 8 years of age, and in 6 girls affected by early puberty (EP) between 8 and 10 years of age.

Results: Direct sequencing of the KISS1R (GPR54) gene revealed two SNPs. One SNP is a missense variant (rs 350,132) that has been previously reported in connection to CPP in Korean girls. The other variant that we found in the GPR54 gene (rs764046557) was a missense SNP located in exon 5 at position 209 of the aminoacid. We identified this variant in only one CPP patient. Automatic sequencing of MKRN3 in all patients revealed three variants in eight subjects. In 6 out of 19 (31.5\%) patients (3/13 CPP patients and 3/6 EP patients) we found the synonymous variant c.663C > T (rs2239669). Another synonymous variant (rs 140467331) was found in one of our CPP patients, as well as one missense variant (rs760981395) in another CPP patient.

Conclusion: In conclusion, we identified sequence variations of the KISSIR and MKRN3 genes, two of the most frequent genetic causes of ICPP. Our results suggest that these variants might be inducible factors in the pathogenesis of CPP.

Keywords: Early onset of puberty, Precocious puberty, Genetic variations, MKRN3 and KISS1R genes, Growth factors

\section{Introduction}

Puberty is a complex biological process of sexual development, controlled at hypothalamic level by activation of pulsatile gonadotropin-releasing hormone $(\mathrm{GnRH})$ secretion, which stimulates hormonal cascade and gonadal activation [1].

Pubertal timing is known to be influenced by interactions among various genetic, nutritional, environmental

\footnotetext{
* Correspondence: mauro.bozzola@unipv.it

'Department of Internal Medicine and Therapeutics, Pediatrics and Adolescent Care Unit, University of Pavia, Via Aselli 43, 27100 Pavia, Italy Full list of author information is available at the end of the article
}

and socio-economic factors, although the ultimate mechanisms underlying the increase in pulsatile $\mathrm{GnRH}$ secretion at puberty have yet to be fully elucidated [2].

Central precocious puberty (CPP) is clinically identified by the development of secondary sexual characteristics such as breast development before 8 years of age in females (B2 according to Tanner classification) and the increase of testicular volume before 9 years of age in boys. Despite efforts to establish the genetic mechanism underlying normal and precocious pubertal timing in humans, it remains largely unknown [2]. However, gain-of-function mutations in the KISS1 and KISSR1 (previously named 
GPR54) genes and loss-of-function mutations in the makorin ring finger protein 3 (MKRN3) gene were shown to lead to CPP [3-6].

Kisspeptin, the peptide product of the KISS1 gene, and its receptor, the G-protein 54 (GPR54) signaling complex, are essential gatekeepers of pubertal activation of GnRH neurons [2, 7-11]. An increase in kisspeptin signaling, caused by enhanced expression of KISS1 and GPR54 genes at onset of puberty, contributes to the activation of the gonadotropic axis. Therefore, gain-offunction mutations in KISS1 or KISSR1 genes may induce precocious activation of puberty.

On the other hand, Abreu et al. [6], using a whole exome sequencing approach, detected deleterious mutations in the gene encoding the makorin ring finger protein 3, which act by inhibiting factors that stimulate pubertal pulsatile GnRH secretion [12].

Since 2014, the role of KISS1, KISS1R and MKNR3 in precocious puberty has been recognized [13]. In this study, we analyzed the DNA sequence of these genes in a number of girls affected by CPP. Furthermore, we investigated the presence of SNPs in the same genes of another group of girls affected by "early" puberty (EP), which is defined as the onset of puberty between 8 and 10 years of age in girls showing breast development before the mean age of normal females. We purposed to verify a possible role of KISS1R and MKRN3 on pubertal timing in these subjects too.

\section{Methods \\ Subjects}

We enrolled 19 female subjects in our study: 13 cases with CPP and 6 with EP. At clinical examination, the patients diagnosed with CPP had to meet the following criteria: above-average height, increased growth rate and advanced bone age (evaluated using Greulich and Pyle Atlas); CPP was confirmed by pelvic ultrasound showing a longitudinal diameter of the uterus of over $3.6 \mathrm{~mm}$ and a high ovarian volume $(>2 \mathrm{ml})$, and serum LH peak above $5 \mathrm{IU} / \mathrm{L}$ after $\mathrm{GnRH}$ stimulation and pituitary MRI scan, in girls under 8 years of age. In girls with anticipated puberty, the same clinical and laboratory features occur between 8 and 10 years of age.

In the girls with early puberty, the onset of pubertal development started between 8 and 10 years of age and rapidly progressed, like in females with precocious puberty. Patients' clinical and hormonal data are shown in Table 1.

Table 1 Clinical and hormonal features of patients

\begin{tabular}{|c|c|c|c|c|c|c|c|c|c|c|c|c|c|c|}
\hline $\begin{array}{l}\text { Patient } \\
\text { number }\end{array}$ & $\begin{array}{l}\text { CCPlearly } \\
\text { puberty (EP) } \\
\text { classification }\end{array}$ & $\begin{array}{l}\text { Initial clinical } \\
\text { manifestati } \\
\text { on (Age, y) }\end{array}$ & $\begin{array}{l}\text { Breast } \\
\text { Tanner } \\
\text { stage }\end{array}$ & $\begin{array}{l}\text { Uterus } \\
\text { length }\end{array}$ & BMI SDS & BA y & $\begin{array}{l}\text { LH aft } \\
\text { GnRH } \\
\text { FSH a } \\
\text { GnRH }\end{array}$ & $\begin{array}{l}e r \\
\text { IU/L } \\
\text { fter } \\
\text { IU/L }\end{array}$ & $\begin{array}{l}E 2 \\
P g / m l\end{array}$ & $\begin{array}{l}\text { Mother's } \\
\text { height } \\
\text { (cm) }\end{array}$ & $\begin{array}{l}\text { Father's } \\
\text { Height } \\
(\mathrm{cm})\end{array}$ & $\begin{array}{l}\text { Mother's } \\
\text { menarche } \\
\text { (age, y) }\end{array}$ & $\begin{array}{l}\text { Mutation } \\
\text { GPR54 }\end{array}$ & $\begin{array}{l}\text { Mutation } \\
\text { MKRN3 }\end{array}$ \\
\hline 1 & EP & 8.5 & 2 & 3.8 & -1.02 & 9.5 & 3,1 & 12.3 & 26 & 154.5 & 172.2 & 10 & rs 350,132 & \\
\hline 2 & EP & 8.5 & 2 & 3.5 & 1.52 & 9 & 9,3 & 15.1 & 27.4 & 153 & & 11 & & rs2239669 \\
\hline 3 & EP & 8.5 & 3 & 4.3 & 0.26 & 10.5 & 10.74 & 8.4 & 22.1 & 157.1 & 171 & 11 & rs 350,132 & rs2239669 \\
\hline 4 & EP & 8.5 & 2 & & -0.24 & & 7.1 & 11.5 & 33.8 & & & & rs 350,132 & \\
\hline 5 & EP & 8.5 & 2 & 4.6 & -1.2 & 8.5 & 42.4 & 12.4 & 18 & 156 & 160.6 & 12 & rs 350,132 & \\
\hline 6 & EP & 8.5 & 2 & & -0.79 & 12 & 4.7 & 6.6 & 10 & & & & & rs2239669 \\
\hline 7 & CCP & 7 & 3 & 4.5 & -1.1 & 11 & 35.8 & 17.6 & $<10$ & 158 & 164 & 11 & rs 350,132 & \\
\hline 8 & CCP & 8 & 3 & 4.2 & -0.9 & 10.5 & 9.3 & 8.8 & 50.5 & 158.1 & 179.9 & 10 & rs 350,132 & \\
\hline 9 & CCP & 8 & 2 & 4 & -1.96 & 8.5 & 5.4 & 7.1 & 20.7 & 168.5 & 173.1 & 13 & rs 350,132 & rs 140467331 \\
\hline 10 & CCP & 6.5 & 2 & 4.2 & 0.15 & 8 & 4.4 & 15.4 & 27.7 & 162.5 & 175.5 & 11 & rs 350,132 & \\
\hline 11 & CCP & 8 & 2 & 3.6 & 0.08 & 10 & 10.3 & 11 & 28.5 & 172.2 & 178.9 & 13 & rs 350,132 & rs2239669 \\
\hline 12 & $\mathrm{CCP}$ & 7.5 & 2 & 5.2 & 0.12 & 10 & 15.7 & 9.9 & 19.2 & 163.9 & 169.1 & 14 & rs 350,132 & \\
\hline 13 & CCP & 7 & 3 & 3.5 & -0.12 & 10.5 & 22.3 & 11.6 & 15.7 & 168 & 187 & 11 & & rs2239669 \\
\hline 14 & CCP & 8 & 2 & 3.1 & -0.47 & 11 & 5.7 & 11.2 & $<10$ & 146.8 & 175.4 & 11 & rs 350,132 & \\
\hline 15 & $\mathrm{CCP}$ & 8 & 2 & 5.4 & 0.62 & & 36.3 & 13.6 & 38.6 & & & & $\begin{array}{l}\text { rs } 350,132 \\
\text { /rs764046537 }\end{array}$ & \\
\hline 16 & CCP & 8 & 3 & 4.8 & -0.16 & 10 & 8.1 & 14.8 & 13.5 & & & & /rs764046537 & \\
\hline 17 & CCP & 8 & 3 & 3.6 & -0.22 & 10.5 & 28.8 & 13.4 & 18 & & & & rs 350,132 & rs2239669 \\
\hline 18 & CCP & 7.5 & & & & 11 & & & & & & & rs 350,132 & rs760981395 \\
\hline 19 & CCP & 5.5 & 2 & 4.5 & & 6 & 5.9 & 25.2 & 15.2 & & & & rs 350,132 & \\
\hline
\end{tabular}


Family history of pubertal precocity was investigated and both parental height and pubertal timing were obtained.

\section{Hormone assays}

Serum levels of LH (luteinizing hormone), FSH (follicle stimulating hormone), and estradiol $\left(E_{2}\right)$ were determined by chemiluminescent immunometric assay (Siemens Medical Solutions Diagnostics, Milan, Italy).

For the GnRH stimulation test, after administration of $100 \mu \mathrm{g}$ of synthetic $\mathrm{GnRH}\left(100 \mathrm{mcg} / \mathrm{m}^{2}\right)$ by intravenous bolus, serial blood samples for LH and FSH measurements were collected at $0,15,30$ and 90 min after GnRH administration. LH assays had a detection limit of $0.1 \mathrm{IU} / \mathrm{l}$. We considered stimulated $\mathrm{LH}$ levels of more than $5 \mathrm{IU} / \mathrm{l}$ as a pubertal cut-off.

\section{Genetic analysis}

Genomic DNA was isolated from peripheral blood mononuclear cells (PBMC) of all patients using the Maxwell 16 Instruments (Promega). All coding exons (exon 1 to 5) and intronic flanking regions of the KISS1R (GPR54) gene were PCR amplified with five specific pairs of primers as previously described [7]. The entire coding region of MKRN3 (GenBank accession number NC_ 000015.1) was amplified by PCR using three pairs of primers as described by Abreu et al. [6]. To confirm the presence of the rs760981395variant in our patients, we used another homemade reverse primer designed with Primer3 software. PCR products were visualized on 1.5\% agarose gel, stained with ethidium bromide in order to verify the presence of PCR products. Then, DNA sequencing reactions were conducted using the same primer pairs and a BigDye Terminator V3.1 Cycle Sequencing Kit (Applied Biosystems, Foster City, CA, USA) in accordance with the manufacturer's instructions. The sequencing reactions were electrophoresed and analyzed using the ABI PRISM 310 genetic analyzer (Applied Biosystem).

\section{Results}

\section{Clinical features}

Patients with CPP and EP had typical clinical and hormonal features of premature activation of the reproductive axis, including early pubertal signs such as breast development, increased growth velocity, advanced bone age, enlarged ovary volume and longitudinal uterine length, elevated E2 levels and elevated GnRH stimulated LH and FSH levels. Detailed clinical parameters are shown in Table 1. The average age at onset of symptoms was $7.46 \pm$ 0.22 years for CPP patients and 8.5 for EP patients (all of whom were 8.5 years old). The median age plus and minus SDS at the time of diagnosis was $8.3 \pm 0.36$ years and $9.2 \pm$ 0.18 years respectively; the median bone age was 10.25 years (range: 9.25-10.75 y) and 9.5 years (range: $8.87-10.87 \mathrm{y}$ ), respectively. The median GnRH stimulated LH level was $9.8 \mathrm{IU} / \mathrm{L}$ (range: $5.8-25.5 \mathrm{IU} / \mathrm{L}$ ) and $8.2 \mathrm{IU} / \mathrm{L}$ (range: 4.7-10.74 IU/L), respectively, while the median GnRH stimulated FSH level was $12.5 \mathrm{IU} / \mathrm{L}$ (range: 10.45-15.1 IU/ L) and 11.9 IU/L (range: 8.4-12.4 IU/L), respectively. The median E2 level was $19.95 \mathrm{pg} / \mathrm{ml}$ (range: $15.7-28.5 \mathrm{pg} / \mathrm{ml}$ ) and $24 \mathrm{pg} / \mathrm{ml}$ (range: $18-27.4 \mathrm{pg} / \mathrm{ml}$ ), respectively. Patients were treated with a depot GnRH agonist resulting in adequate clinical and hormonal regression of pubertal signs and inhibition of auxological progression.

\section{GPR54 and MKRN3 genes analysis}

Direct sequencing of the KISS1R (GPR54) gene revealed two SNPs (Table 2). One SNP is a missense variant (rs350132) that has been previously reported in connection to CPP in Korean girls [14] as well as in the study of another population [15]. We found this SNP in 15/19 (79\%) of our patients (10 were homozygous and 5 heterozygous; in 11/13 CPP patients and 4/6 EP patients). The other variant that we found in the GPR54 gene (rs764046557) was a missense SNP located in exon 5 at position 209 of the aminoacid. We identified this variant in only one CPP patient. This patient was also homozygous for the rs350132 polymorphism. The variant (rs764046557) is known and included in the SNP data base (TOPMed Whole Genome Sequencing (WGS) Project) with a frequency of $\mathrm{T}=0.00002$.

Automatic sequencing of MKRN3 in all patients revealed three variants in eight subjects. In 6 out of 19 (31.5\%) patients (3/13 CPP patients and 3/6 EP patients) we found the synonymous variant c.663C $>\mathrm{T}$ (rs2239669).

Table 2 Mutation position and characteristics: the positions of polymorphisms and mutations are defined according to contig NC_000015.10 for MKN3 gene and NC_000019.10 for GPR54 gene

\begin{tabular}{|c|c|c|c|c|c|c|c|}
\hline$N$ & Gene & Position & Allele & Location & $d b S N P I D$ & N patient & Note \\
\hline 1 & GPR54 & chr19:920642 & $\begin{array}{l}T>A \\
T>C\end{array}$ & Exon 5 & rs 350,132 & 15 & Benign polymorphism \\
\hline 2 & GPR54 & chr19:920421 & $C>T$ & Exon 5 & rs764046537 & 1 & Missense variant \\
\hline 3 & MKRN3 & chr15:23566445 & $\begin{array}{l}C>A \\
C>T\end{array}$ & - & rs2239669 & 6 & Synonymous variant \\
\hline 4 & MKRN3 & chr15:23566883 & $C>T$ & - & rs140467331 & 1 & Synonymous variant \\
\hline 5 & MKRN3 & chr15:23566885 & $C>G$ & - & rs760981395 & 1 & Missense variant \\
\hline
\end{tabular}


According to ExAC, the allele frequency of this polymorphism is 0.2815 [16].

Another synonymous variant (rs140467331) was found in one of our CPP patients, as well as one missense variant (rs760981395) in another CPP patient. These variants are known and included in the SNP data base (ExAC) with a frequency of 0.00002 and 0.00001 , respectively but, to the best of our knowledge, they have not yet been described in scientific papers in connection to CPP. The missense variant caused an aminoacid substitution (Ser to Cys) at position 368.

\section{Discussion}

In pediatric endocrinology practice, precocious puberty is a non-rare condition that can result in short final height and physiological complaints in untreated patients [17]. Increased evidence suggests an association between early timing of puberty and adverse health outcomes in later life such as risk of breast neoplasia.

The onset of puberty varies greatly among individuals and races, and much of this variation is due to genetic factors. Kisspeptin and its receptor, GPR54, appear to be the crucial regulators of puberty [1]. Since 2003, many researchers have attempted to find a molecular mechanism of the kisspeptin/KISS1R system that can be associated with puberty development variation. They found mutations in the GPR54 gene that resulted in idiopathic hypogonadotropic hypogonadism $[1,11,18,19]$.

However, the genetic basis of CPP includes either mutations in the KISS1 and KISS1R genes or loss-offunction mutations in the MKRN3 gene. To date, MKRN3 mutations have been described in 58 patients with CPP from 35 different families [2, 6, 12, 20-24]; these include 23 different loss-of-function and 11 missense mutations of MKRN3 and represent the most frequent genetic cause of CPP since being identified in 2013 [10]. Makorin ring finger protein 3 is codified by an intron less gene on chromosome 15 and is thought to have an inhibitory effect on $\mathrm{GnRH}$ secretion. It belongs to a family of E3 ubiquit in ligases, but its mechanism of action is as yet unknown.

In 2008, an autosomal dominant missense mutation in KISS1R, leading to prolonged activation of intracellular pathways in response to kisspeptin, was suggested as a cause of CPP [4]. Since then, no other CPP cases with activating KISS1R mutations have been reported, but a few KISS1R polymorphisms have been identified in CPP patients $[13,25]$. In this study, we detected one SNP missense variant (rs 350132c.1091 T > A), which had been previously reported in connection to CPP in Korean girls [14] as well as in the study of another population [15]. It is a non-synonymous SNP that induces amino acid substitution of p.Leu364His, and it was considered as a benign polymorphism in three in silico analyses used by Yean Joung Oh et al. [25]. Interestingly, we found this SNP in both groups of patients in our study: CPP and EP patients. Therefore, we can suppose that this variant may also be associated with moderately early onset of puberty. The other variant that we found in the GPR54 gene (rs764046557) was a missense SNP, located in exon 5 of the aminoacid at position 209. We identified this variant in one CCP patient only. These patients were also homozygous for rs 350,132 polymorphism. This variant is known and included in the SNP database (TOPMed Whole Genome Sequencing (WGS) Project) but it has not been previously described in scientific papers as being linked to CPP or to any pathological effect.

Analysis of the MKRN3 gene in all our patients revealed three variants in eight subjects. In 6 out of 19 (31.5\%) patients (3/13 CPP patients and $3 / 6$ early puberty patients) we found the synonymous variant c. $663 \mathrm{C}>\mathrm{T}$. Additive model analysis revealed a significant link between this SNP and precocious puberty in boys but, in contrast, no association was found in CPP girls [26]. However, Ortiz-Cabrera et al. [17] found this variant in $40 \%$ of their female patients (expected frequency 20\%) and they speculated that some SNPs, although silent in relation to the protein aminoacid chain, could affect the expression of post-translational features of the gene, leading to malfunction.

We found another synonymous variant (rs140467331) and one missense variant (rs760981395) in two CPP patients. These variants are known and included in the SNP database (ExAC) but, to the best of our knowledge, they have not yet been described in scientific papers in connection to CPP. The missense variant caused an aminoacid substitution (Ser to Cys) at position 368.

There were no clinical or biological features in our patients suggestive of MKRN3 mutations; in fact, variations were found in both groups, i.e. precocious and early puberty. This is in contrast with other studies in which the authors found a significant difference in the median age between girls with or without mutations [27]. However, it is possible that some patients presented at the hospital at a late pubertal stage and so, the time from the onset of puberty symptoms to diagnosis may not be precise, as it was estimated on data reported by parents.

Our paper confirms the presence (and expands the phenotype) of mutations and polymorphisms of KISS1R and MKRN3 genes, not only in ICPP patients but also in early puberty subjects. However, our study has some limitations: we were not able to perform functional studies to demonstrate the pathogenicity of the variants we found; in addition, it was not possible to obtain DNA samples from the fathers of patients with mutations in order to verify paternal inheritance, which had been demonstrated in previous reports [16]; finally, our sample scale was quite small. 


\section{Conclusions}

We have attempted to identify sequence variations of the KISS1R and MKRN3 genes, two of most frequent genetic causes of $\mathrm{CPP}$, and our findings suggest that these variants might be inducible factors in the pathogenesis of CPP. Furthermore, two recent studies have revealed a negative correlation between circulating MKRN3 levels and the Tanner stages of puberty in healthy children and adolescents [27, 28]. Therefore, screening is recommended, in particular for MKRN3 mutations, for all patients with familial ICPP, patients with unclear family histories [3] and patients with sporadic CPP [2]. It is also important that the younger siblings of patients with familial CPP secondary to MKRN3 mutations be screened for the same mutations. In fact, this approach ensures early diagnosis and prompt $\mathrm{GnRH}$ agonist treatment.

\section{Abbreviations}

FSH: Follicle stimulating hormone; LH: Luteinizing hormone;

GnRH: Gonadotropin releasing hormone; $E_{2}$ : Estradiol; SD: Standard deviation; SDS: Standard deviation score; MKRN3: Makorin ring finger protein 3; KISS1R: (or GPR54): Kisspeptin receptor; CPP: Central precocious puberty; EP: Early puberty

\section{Acknowledgments}

The authors are grateful to Dr. Sheila McVeigh, native-language lector at the University of Pavia, for the English revision of the manuscript.

The authors would like to thank the Adolfo Ferrata Medical Library staff of the University of Pavia (Italy) for their invaluable assistance.

The authors also thank the Onlus "Il Bambino e il suo pediatra", 28066

Galliate (Novara), Italy for logistical support.

\section{Authors' contributions}

$\mathrm{MB}$ and $\mathrm{AV}$ designed the study, revised the manuscript, and approved the final version. SP, VC, CM and GA performed experiments, collected, and analyzed data. SP and EB wrote the manuscript and revised the literature.PF and MG gave technical support and conceptual advice. All authors read and approved the final version of the manuscript.

\section{Funding}

No funding to be declared.

\section{Availability of data and materials}

The datasets used and/or analyzed during the current study are available from the corresponding author on request.

\section{Ethics approval and consent to participate}

Ethics approval and consent to participate. All research was carried out in accordance with the Ethical Standards involving human participants. The study was approved by the "Comitato Etico Area di Pavia", the Ethics Committee of the Foundation IRCCS San Matteo Hospital, on 17th May, 2016 (reference number 20160005680). All participants provided parental written informed consent

\section{Consent for publication}

All participants provided parental written informed consent for publication.

\section{Competing interests}

The authors declare that they have no competing interests.

\section{Author details}

'Department of Internal Medicine and Therapeutics, Pediatrics and Adolescent Care Unit, University of Pavia, Via Aselli 43, 27100 Pavia, Italy. ${ }^{2}$ Immunology and Transplantation Laboratory, Pediatric Hematology and Oncology, Fondazione IRCCS San Matteo, Pavia, Italy. ${ }^{3}$ Department of
Pediatrics, Bambino Gesù Children's Hospital, Rome, Italy. ${ }^{4}$ Institute of Pediatrics, Catholic University, Rome, Italy. ${ }^{5}$ Department of Pediatrics, San Paolo Hospital, Milan, Italy.

Received: 28 November 2019 Accepted: 23 March 2020

Published online: 30 March 2020

\section{References}

1. Rhie JY, Lee KH, Ko JM, Lee WJ, Kim JH, Kim HS. KISS1 gene polymorphisms in Korean girls with central precocious puberty. J Korean Med Sci. 2014;29: 1120-5.

2. Simsek E, Demiral M, Ceylaner S, Kirel B. Two frameshift mutations in MKRN3 in Turkish patients with familial central precocious puberty. Horm Res Paediatr. 2017:87:405-11.

3. Aycan Z, Savas-Erdeve S, Cetinkaya S, Kurnaz E, Keskin M, Sahin NM, et al. Investigation of MKRN3 mutation in patients with familial central precocious puberty. J Clin Res Pediatr Endocrinol. 2018;10:223-9.

4. Teles MG, Bianco S, Brito VN, Trarbach EB, Kuohung W, Xu S, et al. A GPR54 activating mutation in a patient with central precocious puberty. N Engl J Med. 2008:358:709-15.

5. Silveira LG, Noel SD, Silveira-Neto AP, Abreu AP, Brito VN, Santos MG, et al Mutations of the KISS1 gene in disorders of puberty. J Clin Endocrinol Metab. 2010;95:2276-80.

6. Abreu AP, Dauber A, Macedo DB, Noel SD, Brito VN, Gill JC, et al. Central precocious puberty caused by mutations in the imprinted gene MKRN3. N Engl J Med. 2013:368:2467-75.

7. De Roux N, Genin E, Carel JC, Matsuda F, Chaussain JL, Milgrom E. Hypogonadotropic hypogonadism due to loss of function of the KISS1derived peptide receptor GPR54. Proc Natl Acad Sci U. S A. 2003;100: 10972-3.

8. Kotani M, Detheux M, Vanderbogaerde A, Communi D, Vanderwinden JM, Le Poul E, et al. The metastasis suppressor gene KISS-1 encodes kisspeptins, the natural ligands of the orphan protein-coupled receptor GPR54. J Biol Chem. 2001;276:34631-6.

9. Lee JH, Miele ME, Hicks DJ, Phillips KK, Trent JM, Weissman BE, et al. KISS-1, a novel human malignant melanoma metastasis-suppressor gene. J Natl Cancer Inst. 1996:88:1731-7.

10. SeminaraSB MS, Chatzidaki EE, Thresher RR, Acierno IS Jr, Shagoury JK, et al. The GPR54 gene as a regulator of puberty. N Engl J Med. 2003;349:1614-27.

11. Semple RK, Achermann JC, Ellery J, Faroogi IS, Karet FE, Stanhope RG, et al. Two novel missense mutations in $\mathrm{G}$ protein-coupled receptor 54 in a patient with hypogonadotropic hypogonadism. J Clin Endocrinol Metab. 2005;90:1849-55.

12. Schreiner F, Gohlke B, Hamm M, Korsch E, Woelfle J. MKRN3 mutations in familial central precocious puberty. Horm Res Paediatr. 2014;82:122-6.

13. Leka-Emiri S, Chrousos GP, Kanaka-Gantenbein C. The mystery of puberty initiation: genetics and epigenetics of idiopathic central precocious puberty (ICPP). J Endocrinol Investig. 2017;40:789-802.

14. Ko JM, Lee HS, Lee HS, Hwang JS. Genetic variations of GNRHI, GNRHR and GPR54 genes in Korean girls with central precocious puberty. J Korean Soc Pediatr Endocrinol. 2011;16:38-45.

15. Krstevoska-Komstantinova M, Jovanoska J, Tasic VB, Montenegro LR Beneduzzi D, Silveira LR, et al. Mutational analysis of KISS1 and KISSIR in idiopathic central precocious puberty. J Pediatr Endocrinol Metab. 2014;27: 199-201.

16. Ortiz-Cabrera NV, Riveiro-Alvarez R, Lopez-Martinez MA, Perez-Segura P, Aragon-Gomez I, Trujillo-Tiebas MJ, et al. Clinical exome sequencing reveals MKRN3 pathogenic variants in familial and non-familial idiopathic central precocious puberty. Horm Res Paediatr. 2017;87:88-94.

17. Bo RY, Kim HJ, Park HS, Cho YJ, Kim JY, Yee J, et al. Association between MKRN3 and LIN28Bpolynorphisms and precocious puberty. BMC Genet. 2018;19:47-53.

18. Lanfranco F, Gromoll J, von Eckardstein S, Herding EM, Nieschlag E, Simoni M. Role of sequence variations of the $\mathrm{GnRH}$ receptor and $\mathrm{G}$ protein-coupled receptor 54 gene in male idiopathic hypogonadotropic hypogonadism. Eur J Endocrinol. 2005;153:845-52.

19. Tenenbaum-Rakover Y, Commenges-Ducos M, lovane A, Aumas C, Admoni $\mathrm{O}$, de Roux N. Neuroendocrine phenotype analysis in five patients with isolated hypogonadotropic hypogonadism due to a L102P inactivating mutation of GPR54. J Clin Endocrinol Metab. 2007;92:1137-44. 
20. Macedo DB, Abreu AP, Reis AC, Montenegro LR, Dauber A, Beneduzzi D, et al. Central precocious puberty that appears to be sporadic caused by paternally inherited mutations in the imprinted gene makorin ring finger 3. J Clin Endocrinol Metab. 2014:99:E1097-103.

21. Grandone A, Cantelmi G, Cirillo G, Marzuillo P, Luongo C, Miraglia del Giudice $\mathrm{E}$, et al. A case of familial central precocious puberty caused by a novel mutation in the makorin RING finger protein 3 gene. BMC Endocr Disord. 2015;15:60.

22. Neocleus V, Shammas C, PhelanMM NS, Phylactou LA, Skordis N. In silico analysis of a novel MKRN3 missense mutation in familial central precocious puberty. Clin Endocrinol. 2016;84:80-4.

23. De Vries L, Gat-Yablonski G, Drot N, Singer A, Philip M. A novel MKRN3 missense mutation causing familial precocious puberty. Hum Reprod. 2014; 29:2838-43.

24. Oh YJ, Rhie YJ, Nam HK, Kim HR, Lee KH. Genetic variations of the KISSTR gene in Korean girls with central precocious puberty. J Korean Med Sci. 2017;32:108-14.

25. Simon D, Ba J, Mekhail N, Ecosse E, Paulsen A, Zenaty D, et al. Mutations in the maternally imprinted gene MKRN3 are common in familial central precocious puberty. Eur J Endocrinol. 2016;174:1-8.

26. Lazar L, Meyerovitch J, de Vries I, Phillip M, Lebenthal Y. Treated and untreated women with idiopathic precocious puberty: longterm follow up and reproductive outcome between the third and fifth decades. Clin Endocrinol. 2014:80:570-6.

27. Hagen CP, Sorensen K, Mieritz MG, Johansen TH, Almstrup K, Juul A. Circulating MKRN3 levels decline prior to pubertal onset and through puberty: a longitudinal study of healthy girls. J Clin Endocrinol Metab. 2015; 100:1920-6.

28. Busch AS, Hagen CP, Almstrup K, Juul A. Circulating MKRN3 levels decline during puberty in healthy boys. J Clin Endocrinol Metab. 2016;101:2588-93.

\section{Publisher's Note}

Springer Nature remains neutral with regard to jurisdictional claims in published maps and institutional affiliations.

Ready to submit your research? Choose BMC and benefit from:

- fast, convenient online submission

- thorough peer review by experienced researchers in your field

- rapid publication on acceptance

- support for research data, including large and complex data types

- gold Open Access which fosters wider collaboration and increased citations

- maximum visibility for your research: over $100 \mathrm{M}$ website views per year

At $\mathrm{BMC}$, research is always in progress.

Learn more biomedcentral.com/submissions 